\title{
Catatan Diversitas Jamur di Salah Satu Pulau Terluar Republik Indonesia
}

\section{Notes on the Diversity of Macrofungi at one of the Outermost Islands in the Republic of Indonesia}

\author{
MEILISA DWI NURDIYANTI, ASRIE SUHARTI, MEGA PUTRI AMELYA, IVAN PERMANA \\ PUTRA*
}

\author{
Departemen Biologi, Fakultas Matematika dan Ilmu Pengetahuan Alam, Institut Pertanian Bogor, \\ Kampus IPB Dramaga, Bogor 16680
}

Diterima 5 Februari 2020/Disetujui 14 Desember 2020

\begin{abstract}
Marore Island (Province of North Sulawesi) is one of the outermost island in Indonesia. The island is located at the borderline within the Philippines. Till date, there is no publication about islands macrofungi diversity from this island. In fact, the diversity of macrofungi has the potency to support the development of global bioeconomic in Indonesia. The purpose of this study is to make an inventory list of macrofungi on Marore Island in order to enhance the potential in the future. A total was of 22 mushrooms from 13 genera were obtained from this study which were divided into two phylums, namely Basidiomycota and Ascomycota. The identification results confirmed the species obtained: Ganoderma sp.1, Ganoderma sp.2, Ganoderma sp.3, Ganoderma sp.4, Ganoderma sp.5, Ganoderma sp.6, Trametes sp.1, Trametes sp.2, Trametes sp.3, Pycnoporus sp.1, Pycnoporus sp.2, Polyporus sp., Daedalea sp., Lentinus sp., Marasmius sp.1, Marasmius sp.2, Schizophyllum sp., Panellus sp., Tricholoma sp., Phallus sp., Dacryopinax spathularia, and Daldinia sp.
\end{abstract}

Key words: biodiversity, fungi, Indonesia borderline, Marore Island

\section{PENDAHULUAN}

Indonesia merupakan negara kepulauan yang memiliki berbagai tipe ekosistem hutan. Luas hutan di Indonesia tercatat berjumlah 136,730,390.98 ha, baik di daerah terestrial maupun perairan (Kusmana 2011). Selain memiliki tutupan yang luas, hutan Indonesia juga memiliki kelimpahan biodiversitas yang tinggi di dalamnya. Oleh karena itu Indonesia dikenal sebagai negara mega biodiversitas. Salah satu komponen keragaman hayati Indonesia adalah jamur. Gandjar et al. (2006) menyebutkan bahwa diperkirakan terdapat 200,000 spesies jamur yang dapat ditemukan di Indonesia dari total 1.5 juta spesies di seluruh dunia. Namun catatan mengenai biodiversitas jamur di Indonesia belum terdata dengan maksimal, walaupun upaya pencatatan jamur-jamur telah mulai dilakukan, baik pada daerah alami ataupun daerah yang bersinggungan dengan kegiatan antropogenik (Putra et al. 2017, 2018, 2019a, 2019b; Putra 2020a, 2020b, 2020c, 2020d).

*Penulis korespondensi:

E-mail: ivanpermanaputra@apps.ipb.ac.id
Inventarisasi jamur merupakan langkah awal untuk mengenali keragaman dan potensi jamur yang ada disuatu daerah. Informasi mengenai inventarisasi jamur dan potensinya oleh masyarakat lokal di Indonesia telah dilakukan dan dipublikasikan (Putra dan Khafazallah 2020). Namun, catatan mengenai keragaman jamur di Indonesia masih berada dalam jumlah yang sedikit, terutama di pulau-pulau terpencil yang berada di perbatasan negeri. Pulau Marore merupakan salah satu pulau terluar Indonesia yang berbatasan dengan Filipina. Pulau ini termasuk dalam Kabupaten Kepulauan Sangihe, Sulawesi Utara dan berjarak 206 mil laut dengan Manado. Daratan pulau ini terdiri dari perbukitan dengan ketinggian antara $0-150 \mathrm{mdpl}$ dan kemiringan $30^{\circ}$ $50^{\circ}$. Vegetasi utama yang terdapat di pulau ini adalah perkebunan kelapa dan cengkeh, selain itu tanaman yang umum ditemukan adalah nanas, jeruk, bambu, dan singkong (KKP 2019).

Jamur merupakan salah satu jenis organisme yang berperan penting dalam suatu ekosistem, yaitu sebagai dekomposer sehubungan dengan kemampuannya dalam mendegradasi bahan organik (Osono dan Takeda 2006). Selain peranannya dalam sisi ekologis, jamur juga bernilai ekonomis. Spinosa 
(2008) menyebutkan bahwa jamur dapat menjadi sumber pangan dengan nilai gizi tinggi. Selain itu, beberapa jamur diketahui mengandung senyawasenyawa bioaktif yang dapat digunakan sebagai obat. Lange et al. (2012) menyatakan bahwa fungi dapat menjadi salah satu hal potensial untuk menunjang pengembangan bioekonomi global. Pemanfaatan enzim yang dihasilkan oleh fungi sebagai bahan untuk mengkonversi limbah lignoselulosa dalam skala industri dinilai merupakan cara yang paling efisien. Selain itu, fungi juga berperan dalam memproduksi makanan fermentasi yang dapat memperpanjang masa simpan serta memberi nilai tambah nutrisi. Penelitian ini bertujuan melakukan inventarisasi jamur makroskopis di Pulau Marore. Selanjutnya, catatan mengenai biodiversitas jamur ini dapat dikembangkan untuk kajian potensi dan pemanfaatan keragaman jamur di Indonesia.

\section{BAHAN DAN METODE}

Pengambilan sampel dilakukan pada bulan Agustus 2019 di Pulau Marore, Sulawesi Utara (Gambar 1). Metode yang digunakan adalah jelajah secara acak terwakili mengacu pada Puspitaningtyas (2007) dan Priyanti (2008). Sampel jamur yang ditemukan kemudian didokumentasikan menggunakan kamera mirrorless Sony A6000 dengan lensa 16-50 mm. Sampel jamur diberi kode spesimen diamati beberapa karakter makroskopisnya meliputi bentuk tubuh buah, perubahan derajat kebasahan, karakteristik tudung (warna ketika muda dan tua, ukuran, bentuk atas dan bawah, permukaan, tepian, margin), tingkat kebasahan, tipe himenofor (lamela/pori/ gigi), karakteristik stipe (bentuk, warna, ukuran, permukaan, posisi penempelan pada pileus, tipe penempelan pada substrat, flesh of stipe), keberadaan partial veil dan universal veil. Selain itu, pengamatan juga dilakukan terhadap karakteristik kualitatif berupa tekstur, bau tubuh buah, rasa, serta informasi penggunaannya sebagai bahan pangan (edible atau non edible) melalui wawancara dengan key person dan studi literatur untuk mendapatkan data mengenai pengetahuan lokal yang berhubungan dengan pemanfaatan jamur di kawasan tersebut. Berdasarkan karakteristik-karakteristik tersebut, sampel diidentifikasi menggunakan acuan dari Arora (1986), Rokuya et al. (2011), Desjardin et al. (2015). Data lingkungan berupa suhu dan kelembaban udara diukur menggunakan alat thermohigrometer. Potensi spesies jamur terkait dilakukan dengan metode studi literatur.

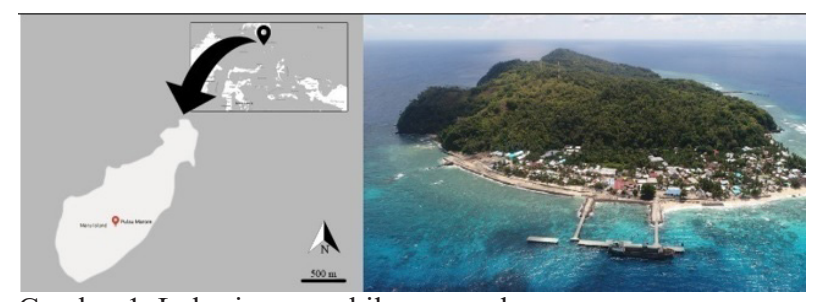

Gambar 1. Lokasi pengambilan sampel

\section{HASIL}

Sebanyak 22 jenis jamur makroskopis didapatkan dari Pulau Marore (Tabel 1). Hasil identifikasi menunjukkan bahwa 21 jenis jamur tergolong dalam filum Basidiomycota, sedangkan 1 jamur lainnya tergolong Ascomycota. Terdapat 2 jamur yang ditemukan tumbuh di substrat tanah (Tricholoma sp. dan Phallus sp.), sedangkan 20 jamur lainnya tumbuh pada kayu. Setiap jamur memiliki karakteristik yang berbeda, berikut merupakan deskripsi karakteristik makroskopis dari masing-masing sampel jamur yang ditemukan.

Daldinia sp. Daldinia sp. ditemukan hidup pada kayu mati secara berkelompok dengan struktur tubuh buah bulat tidak beraturan (Gambar 2a). Warna tubuh buah jamur ini adalah coklat tua dan dalam kondisi kering. Jamur Daldinia sp. saat ditemukan memiliki spora yang tercampur pada serpihan tubuh buah yang berwarna hitam pada permukaannya (Gambar 2b). Tubuh buah jamur ini berukuran $4 \mathrm{~cm}$ dan memiliki tekstur tubuh buah yang keras dengan bau seperti kayu.

Marasmius sp.1. Marasmius sp.1 hidup secara berkelompok dengan jarak antar tubuh buah berdekatan di kayu mati (Gambar 3a). Jamur ini memiliki bentuk tubuh buah tudung berlamela dengan stipe. Tidak terdapat perbedaan warna antara tudung muda dan tua, yaitu putih. Tudung Marasmius sp.1 berdiameter $2.7 \mathrm{~cm}$, berbentuk seperti kipas dengan bentuk atas flat, permukaan smooth, tepian entire, dan margin straight (Gambar 3b). Tingkat kebasahan jamur ini adalah kering ketika ditemukan. Jamur Marasmius sp. 1 memiliki tipe himenofor lamela yang menempel secara adnexed pada stipe (Gambar 3c). Panjang lamela yaitu $0.5 \mathrm{~cm}$ dengan jarak antar baris medium. Stipe Marasmius sp. 1 berbentuk silindris, basal tomentum, berwarna putih kecoklatan, memiliki permukaan smooth, menempel secara central pada pileus, dan memiliki ukuran diameter $0.1 \mathrm{~cm}$ dan panjang $1.2 \mathrm{~cm}$. Flesh of stipe pada jamur ini adalah solid. Marasmius sp.1 memiliki tekstur tubuh buah berdaging dan berbau seperti kayu.

Marasmius sp.2. Marasmius sp.2 hidup secara berkelompok dengan jarak antar tubuh buah sangat dekat pada substrat buah kelapa tua (Gambar 4a). Bentuk tubuh buah jamur ini adalah tudung berlamela dengan stipe. Warna tubuh buah ketika muda adalah oranye, sedangkan ketika tua berubah menjadi putih dengan bagian tengah berwarna kekuningan. Tudung Marasmius sp. 2 berukuran $1.7 \mathrm{~cm}$ dengan bentuk atas funnel shaped, permukaan smooth, tepian entire, dan margin uptuned (Gambar 4b). Tingkat kebasahan jamur ini adalah lembab. Marasmius sp. 2 memiliki tipe himenofor lamela adnexed, memiliki panjang $0.7 \mathrm{~cm}$, dan jarak antar baris yang sedang (Gambar 4c). Stipe jamur ini berbentuk silindris, berwarna putih, basal tomentum, berukuran diameter $0.2 \mathrm{~cm}$ dan panjang $1.2 \mathrm{~cm}$, memiliki permukaan halus (smooth), dan menempel secara central pada pileus. 
Tabel 1 Keragaman jamur asal Pulau Marore

\begin{tabular}{|c|c|c|c|c|}
\hline Filum & Ordo & Famili & Genus & Spesies \\
\hline Ascomycota & Xylariales & Hypoxylaceae & Daldinia & Daldinia sp. \\
\hline \multirow[t]{21}{*}{ Basidiomycota } & Agaricales & Marasmiaceae & Marasmius & Marasmius sp.1 \\
\hline & & & & Marasmius sp.2 \\
\hline & & Mycenaceae & Panellus & Panellus sp. \\
\hline & & Schizophyllaceae & Schizophyllum & Schizophyllum sp. \\
\hline & & Tricholomataceae & Tricholoma & Tricholoma sp. \\
\hline & Dacrymycetales & Dacrymycetaceae & Dacryopinax & Dacryopinax spathularia \\
\hline & Polyporales & Fomitopsidaceae & Daedalea & Daedalea sp. \\
\hline & & Ganodermataceaae & Ganoderma & Ganoderma sp.1 \\
\hline & & & & Ganoderma sp.2 \\
\hline & & & & Ganoderma sp.3 \\
\hline & & & & Ganoderma sp.4 \\
\hline & & & & Ganoderma sp.5 \\
\hline & & & & Ganoderma sp.6 \\
\hline & & Polyporaceae & Lentinus & Lentinus sp. \\
\hline & & & Polyporus & Polyporus sp. \\
\hline & & & Pycnoporus & Pycnoporus sp.1 \\
\hline & & & & Pycnoporus sp.2 \\
\hline & & & Trametes & Trametes sp.1 \\
\hline & & & & Trametes sp.2 \\
\hline & & & & Trametes sp.3 \\
\hline & Phallales & Phallaceae & Phallus & Phallus sp. \\
\hline
\end{tabular}

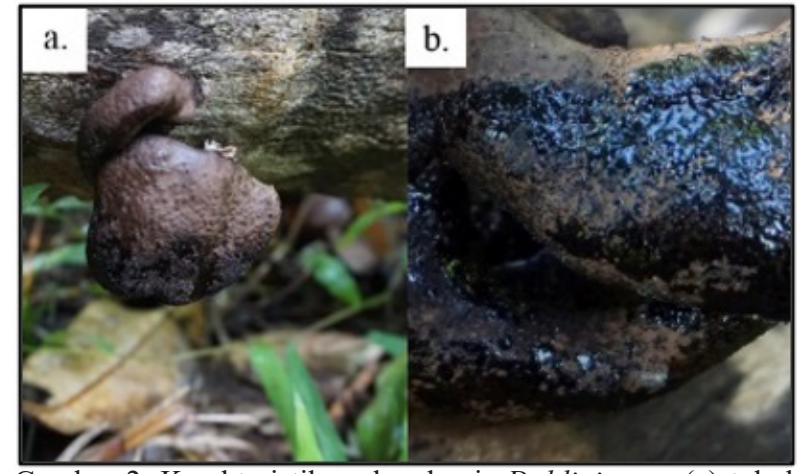

Gambar 2. Karakteristik makroskopis Daldinia sp.: (a) tubuh buah, (b) askokarp yang luruh

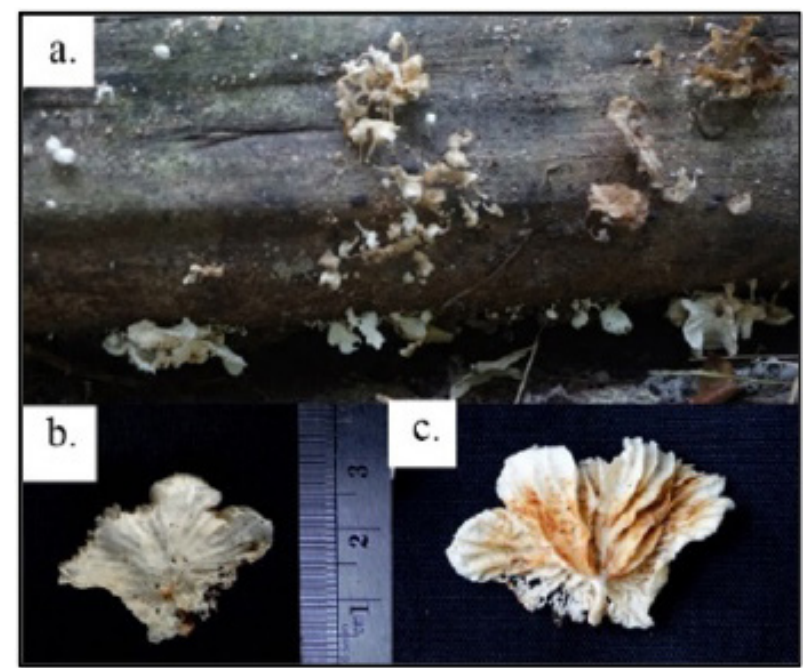

Gambar 3. Karakteristik makroskopis Maramius sp.1: (a) cara tumbuh, (b) tubuh buah, (c) lamela

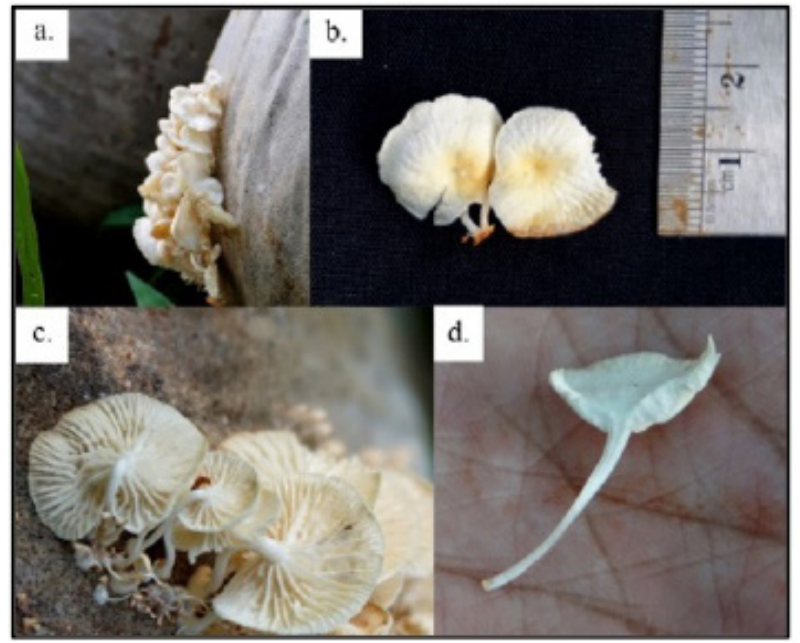

Gambar 4. Karakteristik makroskopis Marasmius sp.2: (a) cara tumbuh, (b) tubuh buah, (c) lamela, (d) stipe

Flesh of stipe jamur ini adalah solid (Gambar 4d). Tekstur tubuh buah Marasmius sp. 2 adalah berdaging dengan bau seperti kayu.

Panellus sp. Panellus sp. hidup di tangkai buah pohon kelapa yang sudah mati secara berkelompok dengan jarak antar tubuh buah berdekatan (Gambar 5a). Bentuk tubuh buah jamur ini adalah tudung berlamela. Tudung Panellus sp. berwarna putih, berukuran 2.5 $\mathrm{cm}$, memiliki bentuk atas funnel shaped, permukaan smooth, tepian entire, dan margin incurved. Tingkat kebasahan jamur ini adalah kering ketika ditemukan. Panellus sp. memiliki tipe himenofor lamela dengan 
jarak antar baris crowded dan memiliki panjang 2.1 $\mathrm{cm}$ (Gambar 5b). Jamur ini melekat pada substrat dengan pseudostipe. Tekstur tubuh buah Panellus sp. adalah berdaging dengan bau seperti kayu.

Schizophyllum sp. Schizophyllum sp. ditemukan tumbuh pada kayu mati secara berkelompok dengan jarak antar tubuh buah yang sangat dekat (caespitose) (Gambar 6a). Bentuk tubuh buah jamur ini adalah tudung berlamela. Warna tudung adalah putih, baik ketika muda maupun tua. Tudung Schizophyllum sp. berukuran $1.7 \mathrm{~cm}$ dengan bentuk atas dan bawah flat, permukaan felty to hairy, tepian lobed, dan margin inrolled (Gambar 6b). Tingkat kebasahaan jamur ini adalah kering. Schizophyllum sp. memiliki tipe himenofor lamela yang berwarna coklat, memiliki jarak antar baris crowded, dan memiliki panjang lamela 1.5 cm (Gambar 6c). Schizophyllum sp. menempel pada substrat dengan pseudostipe (substipitate). Tekstur tubuh buah jamur ini adalah berdaging dengan bau seperti kayu.

Tricholoma sp. Tricholoma sp. hidup secara soliter pada tanah (Gambar 7a). Bentuk tubuh buah jamur ini adalah cap gills with stipe. Jamur ini berwarna putih, dengan bagian tengah tudung berwarna kecoklatan (Gambar 7b). Tudung Tricholoma sp. berdiameter $6.5 \mathrm{~cm}$ dengan bentuk atas funnel shaped, permukaan smooth, dan tepian entire. Tingkat kebasahan jamur ini adalah sedikit lengket (tacky). Tricholoma sp. memiliki tipe himenofor lamela yang menempel secara bebas pada stipe, memiliki panjang $3 \mathrm{~cm}$ dengan jarak antar baris medium (Gambar 7c). Stipe Tricholoma sp. berbentuk silindris, basal tomentum, berwarna putih dengan diameter $1 \mathrm{~cm}$ dan panjang $6.2 \mathrm{~cm}$, permukaan agak bertepung, dan menempel pada bagian centralpileus (Gambar 7d). Flesh of stipe jamur ini adalah solid. Tekstur tubuh buah Tricholoma sp. adalah berdaging dan tidak memiliki bau yang khas.

Dacryopinax spathularia. Dacryopinax spathularia ditemukan hidup pada batang kayu mati secara berkelompok dengan jarak antar tubuh buah berdekatan (Gambar 8a). Bentuk tubuh buah jamur ini adalah silindris dengan ujung memipih. Warna tubuh buah jamur ini adalah kuning, namun akan berubah menjadi oranye setelah mengering. Dacryopinax spathularia memiliki panjang $1 \mathrm{~cm}$ dengan permukaan smooth (Gambar 8b). Jamur ini memiliki tingkat kebasahan lembab. Tekstur tubuh buah seperti jelly dan tidak berbau.

Daedalea sp. Daedalea sp. ditemukan tumbuh pada kayu mati secara berkelompok dengan jarak antar tubuh buah berdekatan (Gambar 9a). Tubuh buah jamur ini berbentuk bracket. Warna tubuh buah jamur ini adalah coklat muda ketika muda, kemudian berubah menjadi putih kecoklatan ketika tua. Tudung Daedalea sp. berdiameter $4.3 \mathrm{~cm}$ dengan bentuk atas arched to semiglobose, permukaan smooth, tepian entire, dan margin straight (Gambar 9b). Tingkat kebasahan jamur ini adalah lembab. Daedalea sp. memiliki tipe himenofor pori yang tidak dapat dilepas, berbentuk bulat melonjong seperti labirin (Gambar 9c). Jamur ini menempel langsung pada substrat (sesil). Tekstur tubuh buah Daedalea sp. kenyal dengan bau yang menyengat.

Ganoderma sp.1. Ganoderma sp.1 ditemukan tumbuh pada kayu mati secara berkelompok dengan jarak antar tubuh buah sangat dekat (Gambar 10a). Jamur ini memiliki bentuk tubuh buah bracket. Tidak terdapat perbedaan warna antara tudung muda dan tua, yaitu berwarna coklat tua dengan tepian coklat muda. Tudung Ganoderma sp. 1 berdiameter $6 \mathrm{~cm}$ dengan bentuk atas flat, permukaan smooth, dan tepian entire (Gambar 10b). Tingkat kebasahan jamur ini adalah kering. Jamur hidup secara langsung pada substrat (sesil) (Gambar 10c). Ganoderma sp.1 memiliki tipe himenofor pori yang bisa dilepas, berbentuk bulat dengan panjang pori $0.1 \mathrm{~cm}$ (Gambar 10d). Tekstur tubuh buah Ganoderma sp. 1 adalah keras dengan bau seperti kayu.

Ganoderma sp.2. Ganoderma sp.2 hidup secara berkelompok pada kayu mati dengan jarak antar tubuh buah berdekatan (Gambar 11a). Ganoderma sp. 2 memiliki bentuk tubuh buah bracket. Warna tudung ketika muda adalah coklat muda kekuningan, sedangkan ketika tua berwarna coklat tua (Gambar 11b). Tudung Ganoderma sp.2 berukuran $7.8 \mathrm{~cm}$ dengan bentuk atas dan bentuk bawah datar (flat), permukaan smooth, dan tepian entire (Gambar 11c). Tingkat kebasahan jamur ini adalah kering. Ganoderma sp.2 memiliki tipe himenofor pori yang tidak dapat dilepas, berbentuk bulat dengan panjang pori $0.2 \mathrm{~cm}$ (Gambar 11d). Jamur ini menempel pada substrat dengan pseudostipe (substipitate). Tekstur tubuh buah Ganoderma sp.2 adalah keras dengan bau rempah.

Ganoderma sp.3. Ganoderma sp.3 hidup di kayu mati secara berkelompok dengan jarak antar tubuh buah berdekatan. Tubuh buah jamur ini berbentuk bracket dan berwarna coklat tua dengan tepian putih baik ketika muda maupun tua (Gambar 12a). Tudung Ganoderma sp. 3 memiliki diameter $5 \mathrm{~cm}$ dengan bentuk atas depressed, permukaan smooth, tepian indented, dan margin upturned (Gambar 12b). Tingkat kebasahan jamur ini adalah kering. Ganoderma sp. 3 memiliki tipe himenofor pori yang dapat dilepas, berbentuk bulat, dengan panjang $0.2 \mathrm{~cm}$. Jamur ini melekat pada substrat menggunakan pseudostipe (substipitate). Tekstur tubuh buah Ganoderma sp.3 adalah keras dengan bau seperti kayu.

Ganoderma sp.4. Ganoderma sp.4 hidup secara berkelompok dengan jarak antar tubuh buah berdekatan pada kayu mati (Gambar 13a). Tubuh buah jamur ini berbentuk bracket dan berwarna coklat dengan tepian coklat muda (Gambar 13b). Tudung Ganoderma sp.4 berdiameter $3 \mathrm{~cm}$ dengan bentuk atas flat, permukaan smooth, tepian entire, dan margin straight. Tingkat kebasahan jamur ini adalah kering. Ganoderma sp.4 memiliki tipe himenofor pori yang dapat dilepas, berbentuk bulat dengan panjang pori $0.5 \mathrm{~cm}$. Jamur ini hidup dengan cara menempel langsung pada substrat (sesil). Tekstur tubuh buah Ganoderma sp.4 keras dan berbau seperti kayu. 


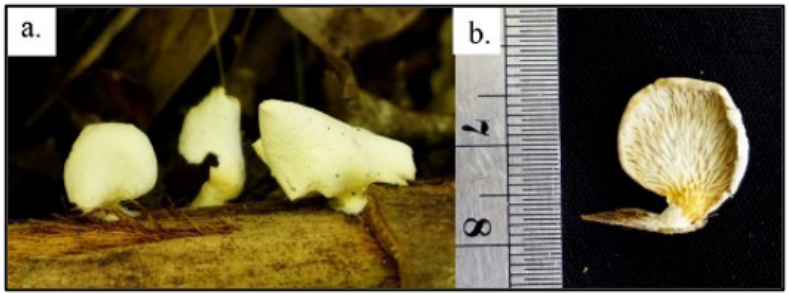

Gambar 5. Karakteristik makroskopis Panellus sp.: (a) cara tumbuh, (b) lamela

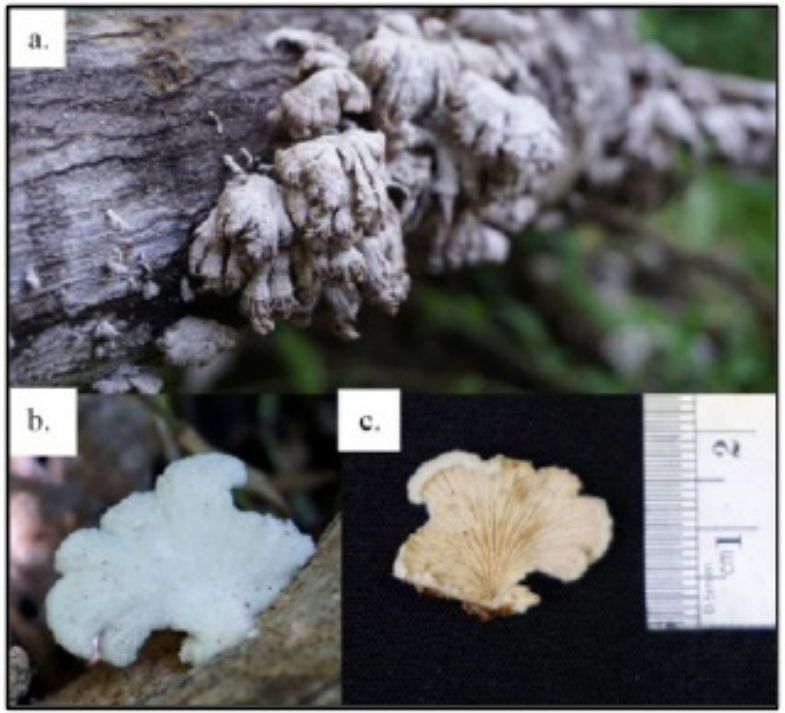

Gambar 6. Karakteristik makroskopis Schizophyllum sp.: (a) cara tumbuh, (b) tubuh buah, (c) lamela

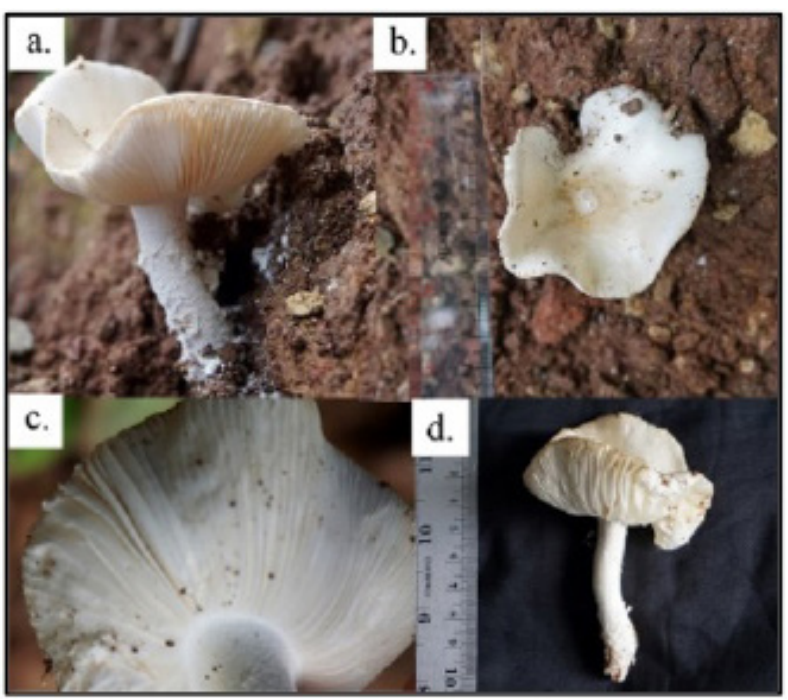

Gambar 7. Karakteristik makroskopis Tricholoma sp.: (a) cara tumbuh, (b) tudung, (c) lamela, (d) stipe

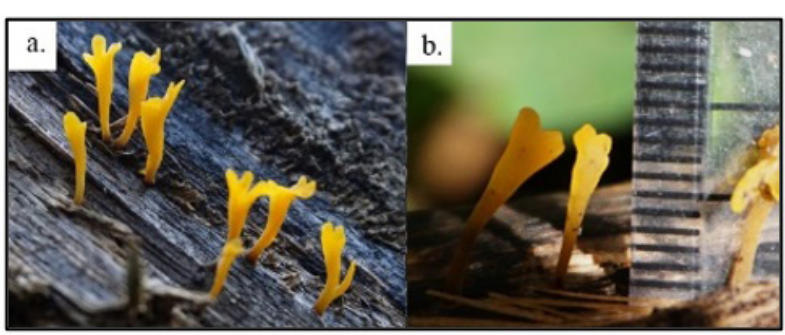

Gambar 8. Karakteristik makroskopis Dacryopinax spathularia.: (a) cara tumbuh, (b) tubuh buah

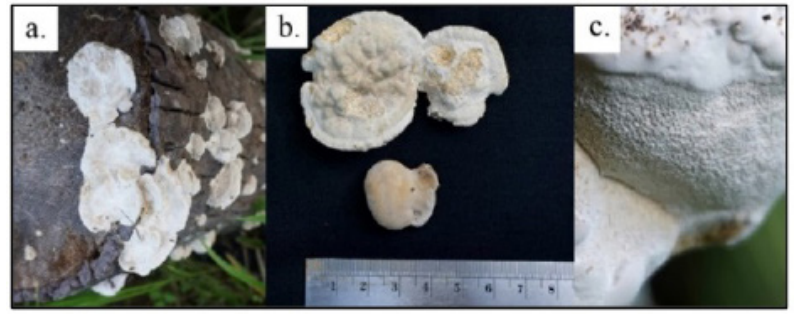

Gambar 9. Karakteristik makroskopis Daedalea sp.: (a) cara tumbuh, (b) tubuh buah, (c) pori

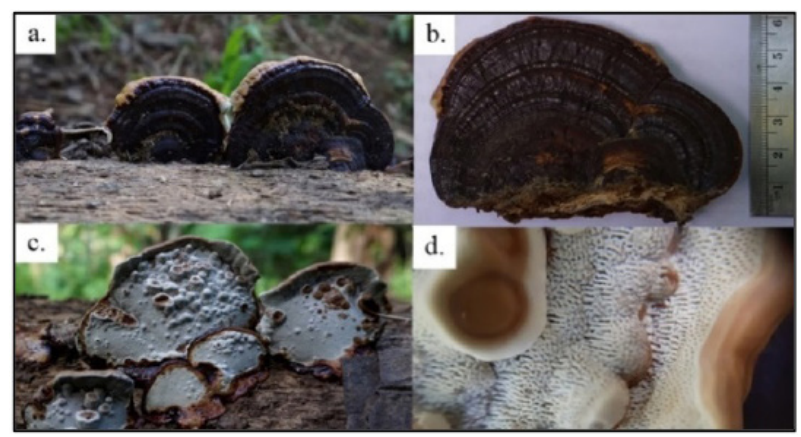

Gambar 10. Karakteristik makroskopis Ganoderma sp.1: (a) cara tumbuh, (b-c) tubuh buah, (d) pori

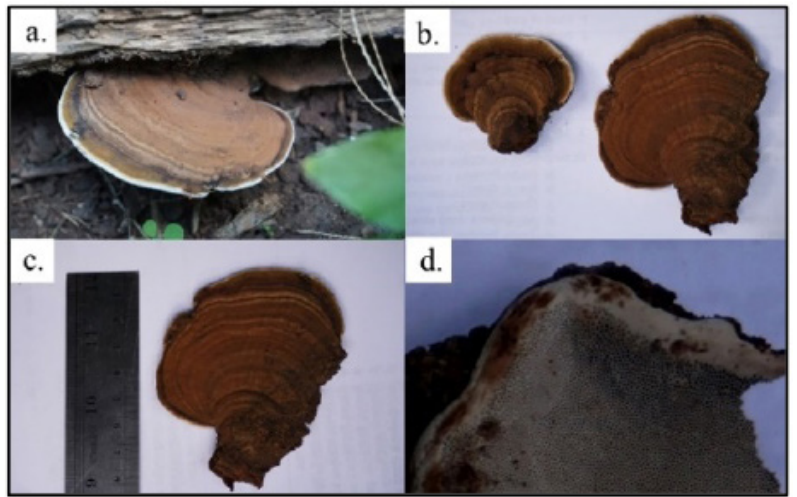

Gambar 11. Karakteristik makroskopis Ganodermas sp.2: (a) cara tumbuh, (b-c) tubuh buah, (d) pori

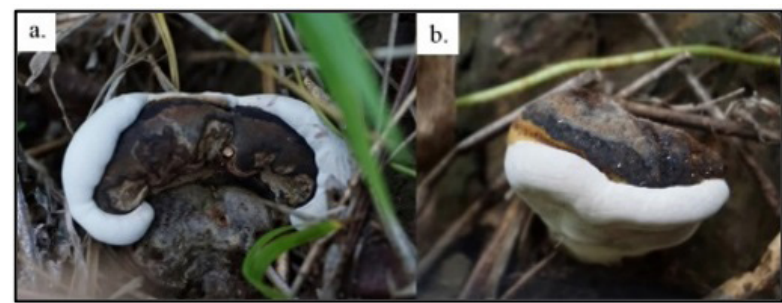

Gambar 12. Karakteristik makroskopis Ganoderma sp.3: (a-b) tubuh buah

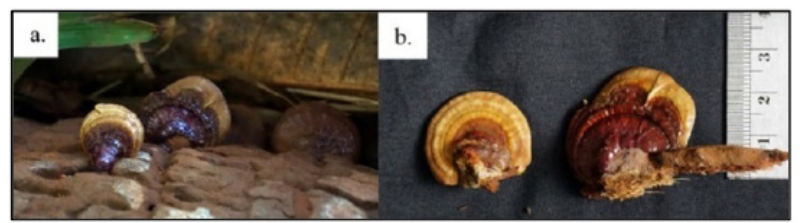

Gambar 13. Karakteristik makroskopis Ganoderma sp.4: (a) cara tumbuh, (b) tubuh buah 
Ganoderma sp.5. Ganoderma sp.5 hidup secara berkelompok dengan jarak antar tubuh buah berdekatan pada substrat berupa kayu mati (Gambar 14a). Tubuh buah Ganoderma sp. 5 berbentuk bracket dengan warna coklat tua. Tudung Ganoderma sp.5 memiliki diameter $7.2 \mathrm{~cm}$ dengan bentuk atas dan bawah flat, permukaan smooth, tepian indented, dan margin straight (Gambar 14b). Tingkat kebasahan jamur ini adalah kering. Ganoderma sp.5 memiliki tipe himenofor pori yang dapat dilepas, berbentuk bulat dengan panjang $0.6 \mathrm{~cm}$ (Gambar 14c). Jamur ini hidup dengan cara menempel langsung pada substrat (sesil). Tekstur tubuh buah Ganoderma sp.5 adalah keras dan berbau seperti kayu.

Ganoderma sp.6. Ganoderma sp.6 ditemukan tumbuh pada kayu mati secara berkelompok dengan jarak antar tubuh buah berdekatan. Bentuk tubuh buah jamur ini adalah bracket dengan warna coklat tua dan memiliki tepian coklat muda dan putih (Gambar 15a). Tudung Ganoderma sp. 6 berukuran $4.2 \mathrm{~cm}$ dengan bentuk atas dan bentuk bawah flat, permukaan smooth, tepian indented, dan margin straight. Tingkat kebasahan jamur ini adalah kering. Ganoderma sp. 6 memiliki tipe himenofor pori yang tidak dapat dilepas, berbentuk bulat dengan panjang $0.4 \mathrm{~cm}$ (Gambar 15b). Jamur ini menempel pada substrat dengan pseudostipe (substipitate). Ganoderma sp. 6 memiliki tekstur tubuh yang keras dan berbau seperti kayu.

Lentinus sp. Jamur Lentinus sp. yang ditemukan di Pulau Marore hidup pada kayu mati secara berkelompok dengan jarak antar tubuh buah berdekatan (Gambar 16a). Bentuk tubuh buah jamur ini adalah tudung berlamela dengan stipe. Tudungnya mengalami perubahan warna yaitu berwarna putih ketika muda dan menjadi putih kecoklatan ketika tua. Tudung Lentinus sp. berdiameter $5.5 \mathrm{~cm}$ dengan bentuk atas funnel shape, permukaan scaly dengan tepian entire dan margin incurved (Gambar 16b). Tingkat kebasahan jamur ini adalah moist. Jamur Lentinus sp. memiliki tipe himenofor lamela dengan penempelan adnexed. Panjang lamela yaitu $2.5 \mathrm{~cm}$ dengan jarak antar baris rapat, dan margin lamela entire (Gambar 16c). Stipe Lentinus sp. berbentuk tapered downward, basal tomentum, berwarna putih, memiliki permukaan scaly, menempel secara central pada pileus, dan memiliki ukuran diameter $0.5 \mathrm{~cm}$ dan panjang $3.5 \mathrm{~cm}$. Flesh of stipe jamur ini adalah solid (Gambar 16d). Jamur ini memiliki tekstur tubuh buah berdaging dan berbau tanah.

Polyporus sp. Polyporus sp. yang ditemukan hidup secara berkelompok dengan jarak antar tubuh buah berdekatan (Gambar 17a). Jamur ini tumbuh di kayu mati dan memiliki bentuk tubuh buah tudung berpori dengan stipe. Tudung Polyporus sp. berwarna coklat muda dengan diameter $5.8 \mathrm{~cm}$, bentuk atas funnel shaped, bentuk bawah flat, permukaan smooth, tepian entire, dan margin incurved (Gambar 17b). Polyporus sp. memiliki tingkat kebasahan kering. Tipe himenofor jamur ini adalah pori yang dapat dilepas, berbentuk ketupat, dan memiliki panjang $0.4 \mathrm{~cm}$ (Gambar 17c). Stipe jamur ini berbentuk silindris, basal tomentum, berwarna putih, memiliki diameter $0.4 \mathrm{~cm}$ dan panjang $0.5 \mathrm{~cm}$, dan permukaan smooth. Flesh of stipe jamur ini adalah solid. Polyporus sp. memiliki tekstur berdaging dengan bau jamur seperti pada umumnya.

Pycnoporus sp.1. Pycnoporus sp. 1 hidup di kayu mati secara berkelompok dengan jarak antar tubuh buah berdekatan (Gambar 18a). Pycnoporus sp.1 memiliki bentuk tubuh buah bracket. Tudung jamur ini berwarna oranye, baik ketika muda maupun tua. Tudung Pycnoporus sp.1 memiliki diameter 3.5 $\mathrm{cm}$ dengan bentuk atas dan bawah flat, permukaan smooth, tepian entire, dan margin straight (Gambar 18b). Tingkat kebasahan jamur ini adalah kering. Tipe himenofor jamur ini adalah pori yang dapat dilepas, berbentuk bulat dengan panjang pori $>0.1 \mathrm{~cm}$ (Gambar 18c). Pycnoporus sp.1 menempel pada substrat dengan pseudostipe (substipitate). Tekstur tubuh buah jamur ini adalah keras dengan bau seperti kayu.

Pycnoporus sp.2. Pycnoporus sp.2 tumbuh secara berkelompok dengan jarak antar tubuh buah berdekatan di kayu mati (Gambar 19a). Bentuk tubuh buah jamur ini adalah bracket. Tidak terdapat perbedaan warna tudung jamur ini ketika muda dan tua, yaitu oranye dengan garis radial berwarna oranye muda (Gambar 19b). Tudung Pycnoporus sp. 2 memiliki diameter 2.5 $\mathrm{cm}$ dengan bentuk atas dan bawah flat, permukaan smooth, dan tepian entire. Tingkat kebasahan jamur ini adalah kering. Pycnoporus sp.2 memiliki tipe himenofor pori yang bisa dilepas, berbentuk bulat dengan panjang pori $0.05 \mathrm{~cm}$ (Gambar 19c). Pycnoporuss sp.2 menempel pada substrat dengan pseudostipe (substipitate). Tekstur tubuh buah jamur ini adalah keras dengan bau seperti kayu.

Trametes sp.1. Trametes sp. 1 hidup di kayu mati secara soliter (Gambar 20a). Bentuk tubuh buah jamur ini adalah bracket. Tudung Trametes sp. 1 berwarna coklat muda dengan tepian putih, berdiameter $12 \mathrm{~cm}$, memiliki bentuk atas depressed, permukaan smooth, tepian entire, dan margin straight. Tingkat kebasahan jamur ini adalah lembab. Trametes sp. 1 memiliki tipe himenofor pori yang tidak dapat dilepas, berbentuk bulat dan memiliki panjang pori $0.3 \mathrm{~cm}$ (Gambar 20b). Tubuh buah jamur ini menempel secara langsung pada substrat (sesil). Trametes sp.1 memiliki tekstur kenyal dan berbau seperti kayu.

Trametes sp.2. Trametes sp.2 hidup di kayu mati secara berkelompok dengan jarak antar tubuh buah berdekatan (Gambar 21a). Bentuk tubuh buah jamur ini adalah bracket. Warna tubuh buah Trametes sp. 2 adalah coklat baik ketika muda maupun tua. Tudung Trametes sp. 2 berdiameter $4 \mathrm{~cm}$ dengan bentuk atas dan bawah flat, memiliki permukaan smooth, tepian entire, dan margin incurved (Gambar 21b). Tingkat kebasahan jamur ini adalah kering. Trametes sp. 2 memiliki tipe himenofor pori yang dapat dilepas, berbentuk pentagonal dengan panjang $0.2 \mathrm{~cm}$ (Gambar 21c). Jamur ini tumbuh dengan cara menempel langsung pada substrat (sesil). Tekstur tubuh buah Trametes sp.2 adalah lunak dan berbau seperti ikan asin. 


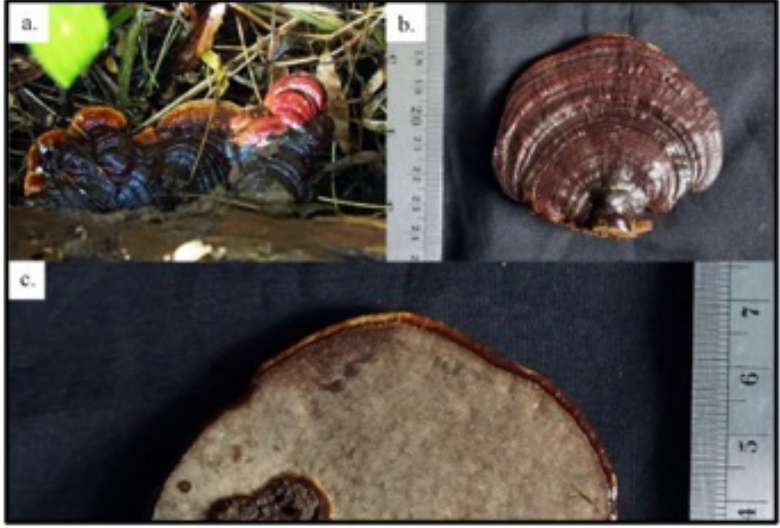

Gambar 14. Karakteristik makroskopis Ganoderma sp.5: (a) caratumbuh, (b) tubuh buah, (c) pori

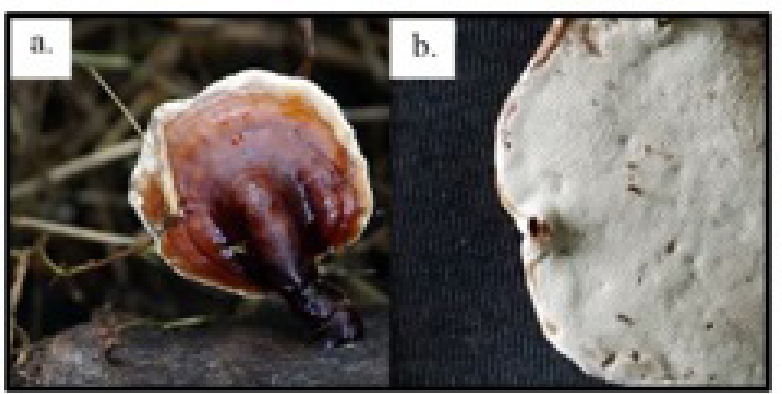

Gambar 15. Karakteristik makroskopis Ganoderma sp.6: (a) tubuh buah; b) pori

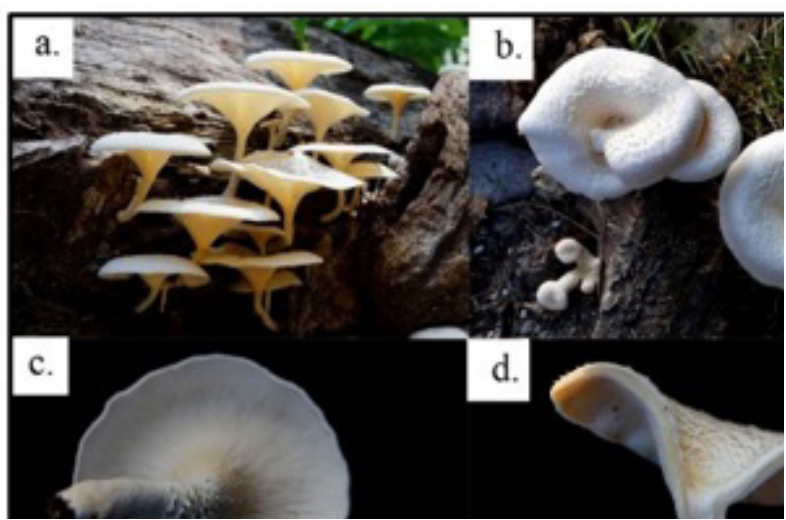

Gambar 16. Karakteristik makroskopis Lentinus sp.: (a) cara tumbuh, (b) tudung, (c) lamela, (d) stipe

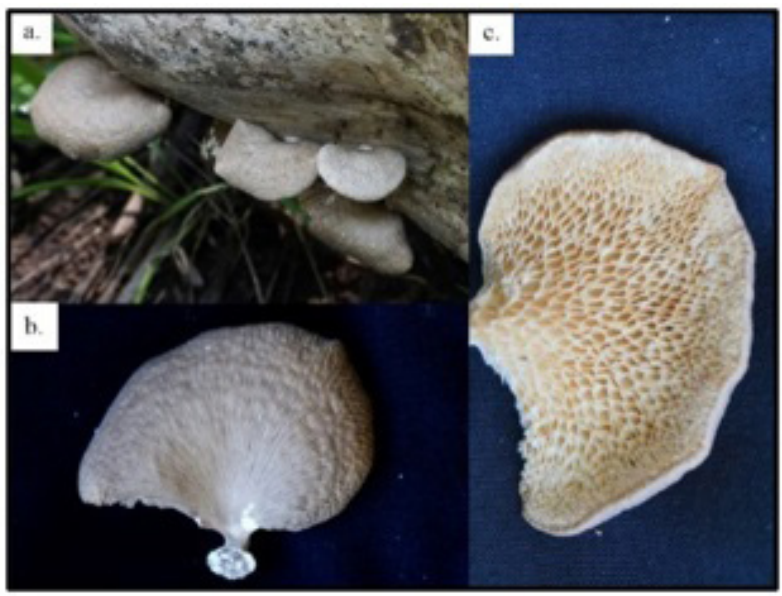

Gambar 17. Karakteristik makroskopis Polyporus sp.: (a) cara tumbuh, (b) tubuh buah, (c) pori

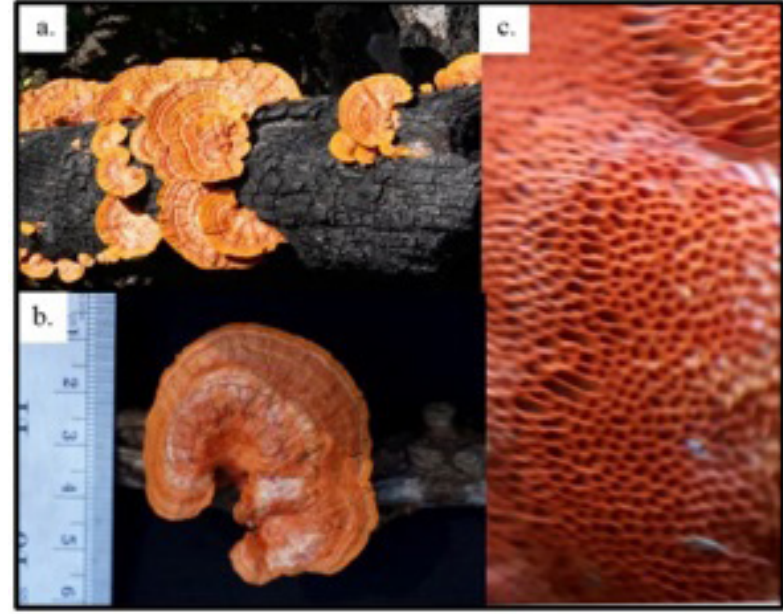

Gambar 18. Karakteristik makroskopis Pycnoporus sp.1: (a) cara tumbuh, (b) tubuh buah, (c) pori

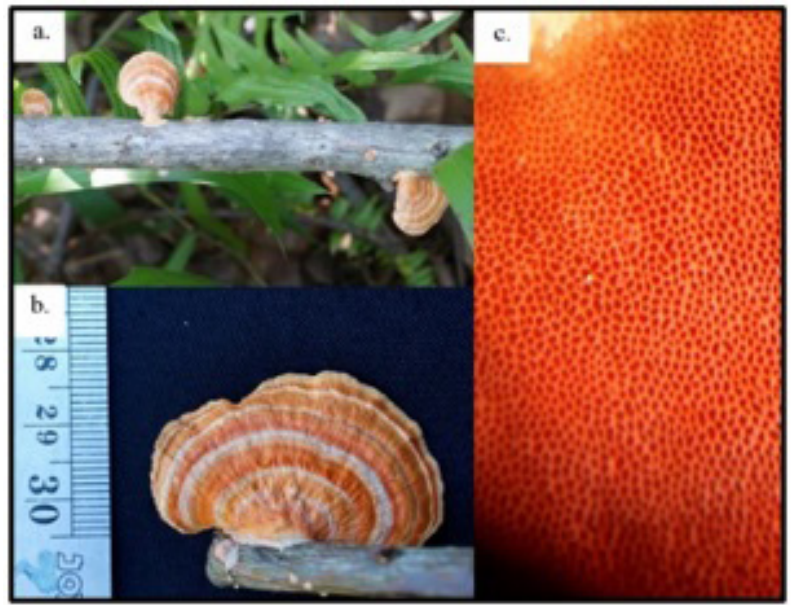

Gambar 19. Karakteristik makroskopis Pycnoporus sp.2: (a) cara tumbuh, (b) tubuh buah, (c) pori

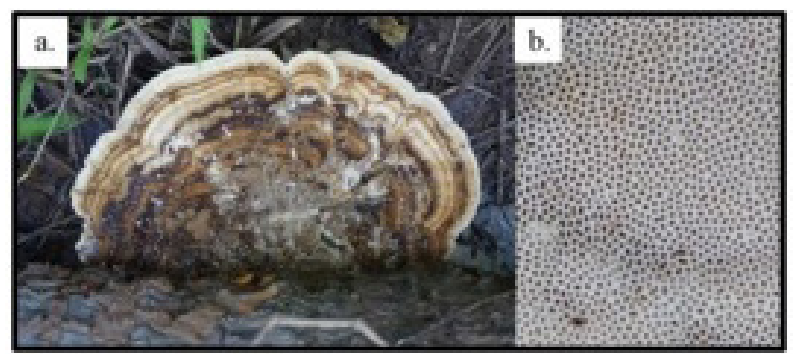

Gambar 20. Karakteristik makroskopis Trametes sp.1: (a) tubuh buah, (b) pori

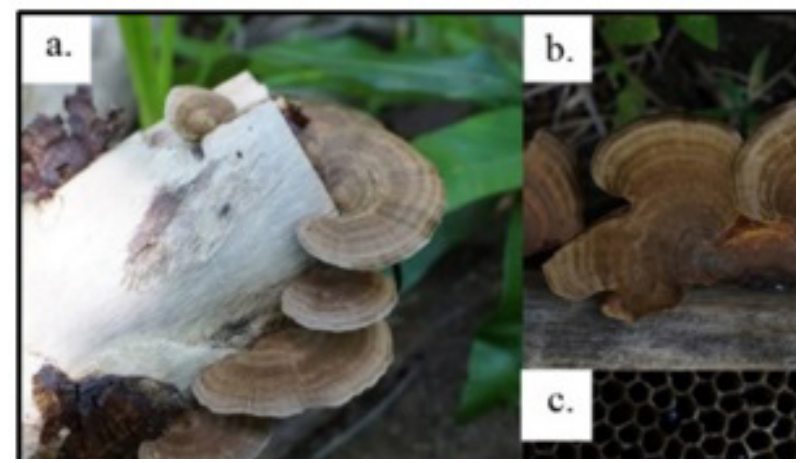

Gambar 21. Karakteristik makroskopis Trametes sp.2: (a-b) tubuh buah, (c) pori 
Trametes sp.3. Trametes sp.3 ditemukan hidup secara berkelompok pada kayu dengan jarak antar tubuh buah sangat dekat (Gambar 22a). Bentuk tubuh buah Trametes sp. 3 adalah bracket dan berwarna coklat baik ketika muda maupun tua. Tudung Trametes sp. 3 berdiameter $3 \mathrm{~cm}$ dengan bentuk atas dan bentuk bawah flat, permukaan berbulu, tepian entire, dan margin upturned. Tingkat kebasahan jamur ini adalah kering. Trametes sp. 3 memiliki tipe himenofor pori yang dapat dilepas, berbentuk bulat dengan panjang $0.2 \mathrm{~cm}$ (Gambar 22b). Cara hidup Trametes sp. 3 adalah menempel secara langsung pada substrat (sesil). Tekstur tubuh buah jamur ini adalah lunak dan memiliki bau seperti jamur pada umumnya.

Phallus sp. Jamur ini ditemukan hidup di tanah tumbuh secara soliter. Bentuk tubuh buahnya adalah hood with stipe. Terdapat indusium berwarna putih yang menyelebungi tubuh buah jamur ini dengan kondisi yang telah rusak kemungkinan dikarenakan kondisi lingkungan serta siklus hidup yang cepat (Gambar 23a). Panjang jamur ini mencapai $9 \mathrm{~cm}$ (Gambar 23b). Stipe Phallus berongga dan terdapat rhizomorph pada pangkalnya.

\section{PEMBAHASAN}

Vegetasi dari Pulau Marore sebagian besar terdiri atas perkebunan kelapa dan cengkeh sehingga memiliki daerah naungan yang cukup luas dengan intensitas cahaya rendah pada lantai hutannya. Suhu lingkungan di Pulau Marore pada saat dilakukan penelitian adalah $\pm 31^{\circ} \mathrm{C}$ dengan kelembaban sekitar 80-90\%. Menurut Alexopoulus et al. (1996), jamur

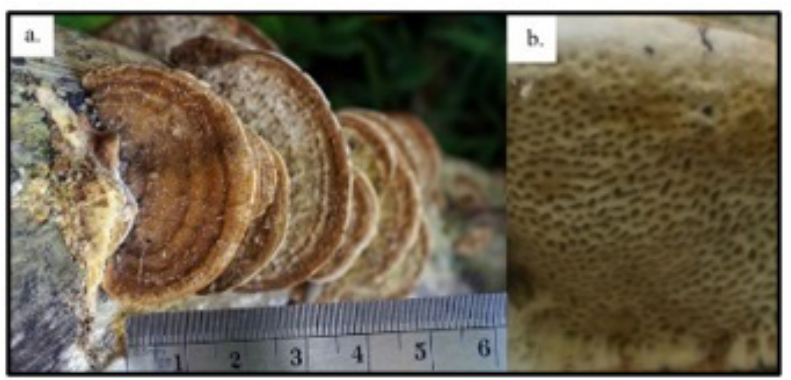

Gambar 22. Karakteristik makroskopis Trametes sp.3: (a) tubuh buah, (b) pori

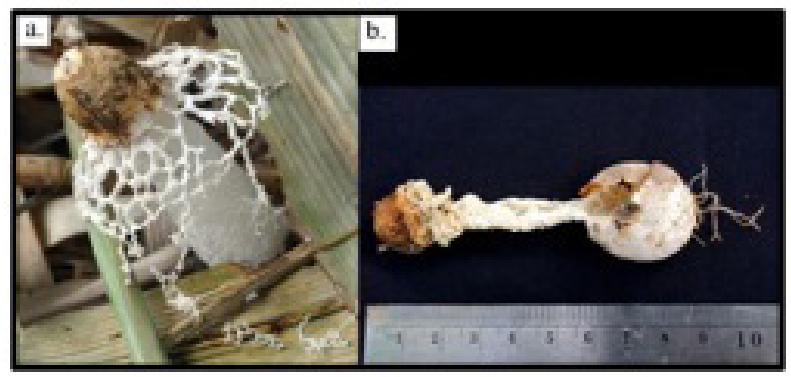

Gambar 23. Karakteristik makroskopis Phallus sp.: (a) tubuh buah (b) stipe makro lebih menyukai hidup pada lingkungan dengan suhu dan intesitas cahaya yang rendah, serta kelembaban yang tinggi. Oleh karena itu, jamur kerap ditemukan pada vegetasi hutan yang rindang, lembab dan tertutup naungan. Kondisi lingkungan di Pulau Marore mampu mendukung perkembangan jamur makro.

Sebanyak 21 jenis jamur filum Basidiomycota dan satu jenis jamur filum Ascomycota berhasil diidentifikasi dari Pulau Marore. Kelompok Basidiomycota didominasi oleh ordo Polyporales yang terdiri dari tiga famili yaitu Fomitopsidaceae (1 spesies), Ganodermataceae (6 spesies), dan Polyporaceae (7 spesies). Keadaan lingkungan Pulau Marore saat eksplorasi berada dalam kondisi kering akibat kemarau sehingga jamur yang mendominasi adalah kelompok jamur Polyporales yang tumbuh pada kayu mati. Ordo Polyporales memiliki ciri utama yaitu himenofor yang bertipe pori, tubuh buah menyerupai kipas, dan kering. Menurut Sippola et al. (2004), banyak spesies dari jamur Polyporales dapat hidup tahunan dan tahan dalam kondisi kering. Selain itu, Polyporales merupakan jamur saprof yang hidup di kayu dan memiliki peran sebagai dekomposer.

Kelompok pertama dari Polyporales yang berhasil dikoleksi yaitu Famili Ganodermataceae yang terdiri dari enam spesies. Ganodermataceae merupakan kelompok paling besar dari ordo Polyporales dan bersifat kosmopolitan. Identifikasi spesies Ganodermataceae diketahui memiliki tingkat kesulitan yang cukup tinggi karena adanya variasi genetik dan diferensiasi geografi yang tinggi (Hapuarachchi et al. 2015). Muspiah et al. (2016) menyatakan bahwa Ganoderma umumnya memiliki tubuh buah berbentuk setengah lingkaran atau seperti kipas, tebal, bertekstur seperti kayu, dan keras. Tekstur yang terlalu keras ini menjadi alasan Ganoderma tidak disarankan untuk dikonsumsi. Seluruh spesies Ganoderma yang ditemukan di lokasi penelitian memiliki variasi pada bentuk tubuh buah, tekstur, ketebalan tubuh buah, kondisi permukaan tubuh buah, bagian pinggir tubuh buah, serta ada atau tidak adanya stipe. Menurut Hapuarachchi et al. (2018), jamur Ganoderma bersifat parasit fakultatif yang dapat menyebabkan penyakit busuk pada akar, namun dapat juga hidup sebagai saprof pada tunggul kayu. Jamur Ganoderma yang ditemukan di Pulau Marore seluruhnya hidup di kayu yang sudah mati. Selain memiliki peran sebagai dekomposer, beberapa spesies dari Ganoderma juga dimanfaatkan sebagai obat (Hapuarachchi et al. 2018).

Anggota ordo Polyporales selanjutnya yaitu Famili Poryporaceae yang terdiri dari empat genus 
yaitu Trametes (3 spesies), Pycnoporus (2 spesies), Polyporus (1 spesies), dan Lentinus (1 spesies). Famili Poryporaceae bersifat saprofit dan memiliki peran penting dalam komponen ekosistem hutan. Kelompok Poryporaceae secara umum memiliki tubuh buah dengan tudung, lunak, dan dengan ciri utama memilki tipe himenofor berbentuk pori (Vlasenko dan Vlasenko 2015). Jamur Lentinus merupakan jamur yang unik karena tidak memiliki ciri seperti Poryporaceae lainnya, melainkan memiliki bentuk tubuh buah bertudung dengan himenofor lamela. Anggota ordo Polyporales lainnya yaitu Famili Formitopsidaceae. Famili ini terdiri dari satu spesies yaitu Daedalea sp. Menurut Han et al. (2015), genus Daedalea ditandai dengan ciri tubuh buah berbentuk seperti kipas, tersusun bertumpuk, dan himenofor tipe pori (daedaleoid). Jamur ini juga termasuk jamur yang dapat bertahan tahunan karena dapat beradaptasi dengan baik pada kondisi kering, serta dapat menyebabkan dekomposisi tipe busuk coklat pada tumbuhan berkayu (Santos et al. 2018).

Kelompok Basidiomycota yang paling banyak dikoleksi setelah Polyporales yaitu ordo Agaricales. Kelompok Agaricales terdiri dari empat famili yaitu Marasmiaceae (2 spesies), Schizophyllaceae (1 spesies), Mycenaceae (1 spesies), dan Tricholomaraceae (1 speises). Marasmiaceae yang berhasil diidentifikasi terdiri dari dua spesies yaitu Marasmius sp. 1 dan Marasmius sp.2. Keduanya memiliki perbedaan yang jelas pada ukuran tubuh buah, corak tudung, dan warna tubuhnya. Menurut Grace et al. (2019), Marasmius umumnya memiliki ciri berukuran kecil, antar lamela berjarak, serta hidup di daun atau kayu yang sudah mati. Marasmius berperan sebagai dekomposer yang penting dari daerah konservasi hingga daerah wisata (Putra et al. 2017, 2018). Peranan Marasmius sebagai dekomposer sangat berpengaruh terhadap siklus nutrisi pada ekosistem di hutan. Genus berikutnya yakni Schizophyllum yang memiliki tipe himenofor lamela. Menurut Kursinah dan Kasiamdari (2015), jamur Schizophyllum commune memiliki tudung berbentukflabelliform, orbicular, dan semi-circular, dengan bagian atas berwarna putih sampai kekuningan. Jamur ini juga dikenal dengan nama jamur gerigit pada beberapa daerah di Indonesia. Schizophyllum memiliki kemampuan yang baik dalam mendegradasi lignin sehingga digolongkan ke dalam kelompok jamur pelapuk putih. Menurut Anita et al. (2011), Schizophyllum dapat digunakan untuk biodelignifikasi kayu sengon. Selain itu, beberapa penelitian menyatakan bahwa Schizophyllum termasuk jamur yang dapat dimakan (edible) (Annissa et al. 2017), obat anti kanker, serta penambah kekebalan tubuh bagi manusia (Ooi dan Liu 2000).

Jamur selanjutnya yang termasuk ke dalam anggota ordo Agaricales adalah dari genus Panellus dan Tricholoma. Panellus ditemukan menempel pada dahan pohon kelapa yang telah mati. Umumnya Panellus memiliki tubuh buah berdaging yang moist tetapi kondisi jamur saat ditemukan kering sehingga tubuh buahnya mengkerut. Jamur ini memiliki pseudostipe untuk menempel pada substrat. Menurut Jančovičová et al. (2016), Panellus memiliki ciri pleurotoid yaitu pada tubuh buahnya tidak memiliki stipe dan langsung tumbuh dari substrat. Penelitian yang telah dilakukan oleh Imamuddin dan Suliasih (2003) menyebutkan bahwa Panellus merupakan jamur perusak kayu dan tidak untuk dimakan. Namun, penelitian lain menyatakan bahwa masyarakat Jepang menganggap Panellus khususnya Panellus serotinus sebagai jamur yang paling enak untuk dikonsumsi (Inoue $e t$ al. 2013). Jamur yang ditemukan berikutnya adalah Tricholoma. Jamur ini merupakan satu-satunya jamur yang tumbuh di tanah dari total empat jamur anggota ordo Agaricales yang ditemukan. Menurut García et al. (2014), Tricholoma memiliki variasi tipe penempelan lamela pada stipe, terkadang free, adnexed, adnate, sinuate, atau decurrent. Jamur ini juga memiliki spora amyloid atau inamyloid dan biasa tumbuh di atas tanah yang ternaungi pepohonan, pada inang yang masih hidup maupun pada padang rumput (García et al. 2014). Jamur ini merupakan jamur yang tidak beracun dan dapat dikonsumsi tetapi belum ada data penelitian terkait pemanfaatan Tricholoma di Pulau Marore sebagai bahan pangan.

Famili berikutnya adalah Phallaceae yang diwakili oleh Phallus sp. Ciri utama jamur dari jenis ini adalah keberadaan indusium berbentuk jaringjaring di tubuh buahnya. Phallus memiliki fase telur, tubuh buah tegak, dan gleba berbau busuk (Li et al. 2014).Pada penelitian ini, penentuan identitas hingga level spesies sulit dilakukan karena kondsi indusium yang telah rusak. $P$. indusiatus dan $P$. duplicatus memiliki ciri yang sama namun dibedakan dari panjang indisiumnya. Menurut Moreno et al. (2009), Phallus merupakan jenis dengan persebaran yang cukup luas dan dapat tumbuh pada substrat tanah, pasir, dan kayu lapuk. Penelitian dari Debnath et al. (2019) menyatakan bahwa Phallus sp. dapat dimanfaatkan sebagai aphrodisiac, obat tipus, pereda nyeri akibat persalinan, dan obat luka bakar. Famili berikutnya adalah Dacrymycetaceae dengan jenis Dacryopinax spathularia. Seluruh tubuh buah jamur ini berwarna kuning cerah dan ditemukan hidup pada kayu lapuk. Menurut Castro- 
Santiuste et al. (2020), Dacryopinax memiliki ciri basidioma berbentuk silindris ketika muda dan dapat berkembang menjadi stipitate/substipitate, cup-shaped, spathulate, petaloid, lobulated, bahan morchelloid pileus ketika dewasa. Tubuh buah Dacryopinax bertekstur gelatin hingga cartilaginous dan warnanya berkisar antara kuning dan oranye hingga coklat. Kumar et al. (2019) menyebutkan bahwa Dacryopinax memiliki aktifitas antimikroba sehingga berpotensi untuk dikembangkan sebagai bahan obat antibakteri. D. spathularia diketahui mengandung senyawa alkaloid, flavonoid, tannin, saponin, dan fenol. Kendati demikian, belum ada catatan mengenai pemanfaatan jamur ini sebagai obat secara langsung di lokasi penelitian, diduga karena ukuran jamur ini yang kecil sehingga biomassa yang umum ditemukan di alam juga berada dalam jumlah yang rendah.

Satu-satunya Ascomycota yang ditemukan di Pulau Marore berasal dari ordo Xylariales, yaitu Daldinia sp. Tubuh buah yang ditemukan berwarna hitam keunguan dan telah rusak pada sepertiga bagian penutup askomanya sehingga terlihat serbuk hitam yang merupakan kumpulan dari askospora. Menurut Yuyama et al. (2013), Daldinia memiliki karakteristik utama yaitu terdapat formasi belang hitam pada stromata dengan diameter yang bervariasi antar individu spesies. Trung et al. (2019) menyebutkan bahwa Daldinia merupakan jamur yang berpotensi menjadi sumber obat sehubungan dengan kandungan senyawa bioaktif yang merupakan metabolit sekundernya. Selain itu, menurut Debnath et al. (2019), bubuk dari tubuh buah Daldinia dapat digunakan sebagai obat luka bakar, gatal, dan beberapa infeksi kulit lainnya.

\section{UCAPAN TERIMA KASIH}

Penulis mengucapkan terima kasih kepada Pemda Kabupaten Kepulauan Sangihe, Pangkalan TNI AL Tahuna, Observasi Wahana Alam IPB, Uni Konservasi Fauna IPB, Divisi Mikologi Departemen Biologi IPB, dan Klub Jamur Biologi IPB yang telah membantu penelitian ini.

\section{DAFTAR PUSTAKA}

[KKP] Kementerian Kelautan dan Perikanan. 2019. Profil 31 Pulau-pulau Terluar Berpenduduk. Indonesia: KKP.

Alexopoulus CJ, Blackwall M, Mims CW. 1996. Introductory Mycology Fourth Edition. New York: John Wiley and Sons, Inc.

Anita SH, Yanto DHY, Fatriasari W. 2011. Pemanfaatan lignin hasil isolasi darilindi hitam proses biopulping bambu betung (Dendrocalamus asper) sebagai media selektif jamur pelapuk putih. J Penelitian Hasil Hutan 29: 312-321.
Annissa I, Ekamawanti HA, Wahdina. 2017. Keanekaragaman jenis jamur makroskopis di Arboretum Sylva Universitas Tanjungpura. J Hutan Lestari 5:969-977.

Arora D. 1986. MushroomsDemystified. USA: TeenSpeedPress,

Castro-Santiuste S, Sierra S, Guzmán-Dávalos L, Cifuentes J, Evans T, Martínez-González CR, Alvaradosizzo H, LunaVega I. 2020. Dacryopinax (Fungi: Dacrymycetales) in Mexico. Phytotaxa 446:006-022

Debnath S, Debnath B, Das P, Saha AK. 2019. Review of an ethno medicinal practices of wild mushrooms by the local tribes of India. Journal of Applied Pharmaceutical Science 9:144-156

Desjardin DE, Wood M, Stevens FA. 2015. California mushrooms: The Comprehensive Identification Guide. Portland:Oregon.

Gandjar I, Sjamsuridzal W, Oetari A. 2006. Mikologi Dasar dan Terapan. Jakarta: Yayasan Obor Indonesia.

García MS, Matheny PB, Palfner G, Lodge DJ. 2014. Deconstructing the Tricholomataceae (Agaricales) and introduction of the new genera Albomagister, Corneriella, Pogonoloma and Pseudotricholoma. Taxon 63:993-1007.

Grace CL, Desjardin DE, Perry BA, Shay JE. 2019. The genus Marasmius (Basidiomycota, Agaricales, Marasmiaceae) from Republic of São Tomé and Príncipe, West Africa. Phytotaxa 414:055-104.

Han ML, Vlasák J, Cui BK. 2015. Daedalea americana sp. nov. (Polyporales, Basidiomycota) evidenced by morphological characters and phylogenetic analysis. Phytotaxa 204:277286.

Hapuarachchi KK, Karunarathna SC, Phengsintham P, Kakumyan P, Hyde KD, Wen TCM. 2018. Amauroderma (Ganodermataceae, Polyporales)- bioactivecompounds, beneficial properties and two new records from Laos. Asian Journal of Mycology 1:121-136.

Hapuarachchi KK, Wen TC, Deng CY, Kang JC, Hyde KD. 2015. Mycosphere essays 1: taxonomic confusion in the Ganoderma lucidum species complex. Mycosphere 6:542-559.

Imamuddin H, Suliasih. 2003. Biodiversitas Basidiomycetes di Kecamatan Kelila, Kabupaten Jayawijaya, Provinsi Papua dan manfaatnya sebagai bahan makanan dan obat tradisional. Berita Biologi 6:699-704.

Inoue N, Inafuku M, Shirouchi B, Nagao K, Yanagita T. 2013. Effect of Mukitake mushroom (Panellus serotinus) on the pathogenesis of lipid abnormalities in obese, diabeticob/ obmice. Lipids in Health and Disease 12:1-6.

Jančovičová S, Blanár D, Glejdura S, Kunca V. 2016. Panellus ringens and P. violaceofulvus (Agaricales, Mycenaceae) from Slovakia: morphological and ecological aspects. Folia Oecologica 43:164-175.

Kumar A, Kumar M, Ali S, Lal SB, Sinha MP. 2019. Antipathogenic efficacy of Indian edible macrofungi Dacryopinax spathularia (Schwein) and Schizophyllum commune (Fries) against some human pathogenic bacteriae. Journal of Emerging Technologies and Innovatie Research 6:695-704

Kusmana C. 2011. Forest resources and forestry in Indonesia. Forest Science and Technology 7:155-160 .

Kusrinah, Kasiamdari RS. 2015. Morphological characteristics and kinship relationship of mushroom Schizophyllum commune Fr. J Nat Scien and Math Res 1:65-71.

Lange L, Bech L, Busk PK, Grell MN, Huang Y, Lange M, Linde T, Pilgaard B, Roth D, Tong X. 2012. The importance of fungi and of mycology for a global development of the bioeconomy. Ima Fungus 3:87-92.

Li H, Mortimer PE, Karunarathna SC, Xu J, Hyde KD. 2014. New species of Phallus from a subtropical forest in Xishuangbanna, China. Phytotaxa 163:91-103.

Moreno G, Khalid AN, Alvarado P. 2009. Anew species of Phallus from Pakistan. Mycotaxon 108:457-462. 
Muspiah A, Sukiman, Faturrahman. 2016. Keragaman Ganodermatacecae dari beberapa kawasan Hutan Pulau Lombok. BioWallacea J Ilmiah Ilmu Biologi 2:54-61.

Ooi VEC, Liu F. 2000. Immunomodulation and anti-cancer activity of polysaccharide-protein complexes. Current Medicinal Chemistry 7:715-729.

Osono T, Takeda H. 2006. Fungal decomposition of Abies needle and Betula leaf litter. Mycologia 98:172-179. DOI:10.1 080/15572536.2006.11832689

Priyanti. 2008. Tanaman monokotil di Kampus I dan II UIN Syarif Hidayatullah Jakarta. Al-Kauniyah: Jurnal Biologi 2:29-36

Puspitaningtyas DM. 2007. Orchid inventory and the host in Meru Betiri National Park-East Java. Biodiversitas 8:210-214.

Putra IP, Mardiyah E, Amalia NS, Mountara A. 2017. Ragam jamur asal serasah dan tanah di Taman Nasional Ujung Kulon Indonesia. Jurnal Sumberdaya Hayati 3:1-7.

Putra IP, Sitompul R, Chalisyan N. 2018. Ragam dan potensi jamur makro asal Taman Wisata Mekarsari Jawa Barat. Al-Kauniyah: Jurnal Biologi 11: 133-150. DOI:10.15408/ kauniyah.v11i2.6729

Putra IP, Nasrullah MA, Dinindaputri TA. 2019a. Study on Diversity and Potency of Some Macro Mushroom at Gunung Gede Pangrango National Park. Buletin Plasma Nutfah 25:1-14. DOI:10.21082/blpn.v25n2.2019.p1-14

Putra IP, Amelya MP, Nugara NH, Zamia HZ. 2019b. Notes of some Macroscopic fungi at IPB University Campus Forest: Diversity and Potency. Biota 12:57-71. DOI:10.20414/ jb.v12i2.192

Putra IP. 2020a. Record On Macroscopic Fungi At IPB University Campus Forest: Description and potential utilization. IJOSE 4:1-11.

Putra IP. 2020b. Catatan beberapa jamur makro di Pulau Belitong: Deskripsi dan potensinya note on macro fungi on Belitong Island: Description and potential. Bioeduscience 4: 11-20. DOI:10.29405/j.bes/4111-204416

Putra IP. 2020c. Kasus keracunan Inocybe sp. di Indonesia. In: Prosiding Seminar Nasional Biologi Di Era Pandemi Covid 19. Makassar: Universitas Islam Negeri (UIN) Alauddin Makassar.
Putra IP. 2020d. Komunikasi singkat: Laporan keberadaan jamur beracun Podostroma cf. cordu-damae dari luar Bogor, di Indonesia. Jurnal Konservasi Hayati 16:6570. DOI:10.33369/hayati.v16i2.12408

Putra IP, Khafazallah K. 2020. Catatan Komunitas Pemburu Jamur Indonesia: Kolaborasi Lintas Profesi dan Generasi Mengenai Etnomikologi Jamur-Jamur Indonesia. Sukabumi: Haura Publishing.

Rokuya I, Yoshio O, Tsugia H. 2011. Fungi of Japan. Japan: Yama-Kei Publishers.

Santos CD, Silva RO, Soares ACF, Drechsler-Santos ER, Bezerra JL. 2018. First record of Daedalea ryvardeniana DrechslerSantos and Robledo (Agaricomycetes, Polyporales, Fomitopsidaceae) in the Caatinga area of Bahia, Brazil. The Journal of Biodiversity Data 14:173-176.

Sippola AL, Simila M, Monkkonen M, Jokimaki J. 2004. Diversity of Polyporous fungi (Polyporaceae) in Northern Boreal Forests: effects of forest site type and logging intensity. Scand J For Res 19:152-163.

Spinosa R. 2008. Fungi and sustainability. Fungi 1:38-43.

Trung HV, Ping-Chung K, Nguyen NT, Nguyen TN, Nguyen QTrung, Nguyen TT, Ha VH, Doan LP, Bach LG, YueChiun L, Tian-Shung W, Tran DT. 2019. Characterization of cytochalasins and streoids from Ascomycete Daldinia concentrica and their cytotoxicity. Natural Product Communications 1:1-5.

Vlasenko VA, Vlasenko AV. 2015. Diversity, distribution and ecology of the genus Polyporus south of Western Siberia (North Asia). Current Research in Environmental and Applied Mycology 5:82-91.

Yuyama KT, Pereira J, Maki CS, Ishikawa NK. 2013. Daldinia eschscholtzii (Ascomycota, Xylariaceae) isolated from the Brazilian Amazon: taxonomic features and mycelial growth conditions. Acta Amazona 43:1-8. 